\title{
Newar Language
}

National Cancer Institute

\section{Source}

National Cancer Institute. Newar Language. NCI Thesaurus. Code C154052.

A Sino-T ibetan language spoken by the Newar people of Nepal. 